\title{
農地における土砂流出抑制対策の比較試験 FIELD OBSERVATION OF SEDIMENT RUNOFF REDUCTION METHODS ON FARMLAND
}

\author{
大澤和敏 1 ・山口悟司 2 ・池田駿介 3 ・高椋恵 4 \\ Kazutoshi OSAWA, Satoshi YAMAGUCHI, Syunsuke IKEDA, Kei TAKAMUKU \\ 1 正会員 農博 東京工業大学助手 大学院理工学研究科（†152-8552 東京都目黒区大岡山2-12-1-M1-1） \\ 2学生会員 東京工業大学大学院理工学研究科（同上） \\ 3フェロー会員 工博 東京工業大学教授 大学院理工学研究科（同上） \\ 4学生会員 東京工業大学大学院理工学研究科（同上）
}

\begin{abstract}
In these years, red-soil erosion and runoff have led to agricultural and environmental problems in Okinawa, and effective sediment runoff reduction methods are required for comprehensive sediment management in an entire river basin. A purpose of this study is to grasp the effect of some sediment runoff reduction methods on farmlands. In order to estimate the effect of canopy and residue cover, no-tillage farming, and grass strip on the reduction of sediment runoff, four experimental plots were set up and multi-points simultaneous observations were carried out. The time series of precipitation, discharge, and suspended sediment concentration were measured on several rainfall events and at proper intervals of time. Sediment runoff from each plot was calculated from observed data. From the results, $27 \%$ to $97 \%$ canopy and residue coverage ratio of sugarcane field reduced sediment runoff by $39 \%$ to $92 \%$ as compared with bare land. No-tillage farming reduced sediment runoff by $94 \%$ as compared with bare land. However, $0.6 \mathrm{~m}$ length grass strip which is generally installed in Okinawa did not trap the sediment so much.
\end{abstract}

Key Words : red-soil runoff, sediment runoff reduction methods, field observation, no-tillage farming, grass strips, sugarcane

\section{1. 序論}

微細土砂の生産源として農地などの面源からの流出を 適切に評価することが，流域一貫土砂管理法の策定のた めに必要とされている．面源における土砂生産が顕著で ある沖縄県では，この問題を赤土流出と称して，サンゴ をはじめとする沖縄地方独自の自然形態を破壊する要因 として問題視している. 沖縄県は1994年に「赤土等流出 防止条例」を制定し，各種土木事業に対して濃度による 赤土流出規制を上限 $200 \mathrm{mg} \cdot \mathrm{L}^{-1}$ と定めた。 その結果，開 発工事現場において適切な対策を行うようになったため, 開発工事に起因する土砂流出量は著しく減少した. 一方, 現在でも経常的な土砂流出発生源である農地は各種営農 的対策の効果が定量的に把握されておらず，農業者の負 担も大きいために規制の対象外となっているが，沖縄県 としては，近い将来規制対象にする方針である．その際 の規制の方法としては, 植生帯(グリーンベルト), 不耕 起栽培, マルチングなど何らかの赤土流出抑制対策を講 じることを義務付けることが検討されている.

そこで, 本研究では沖縄県石垣島の実際に営農されて
きた畑地において同一条件の4つの試験区を設置し，土 砂流出抑制対策に伴う侵食量の削減量を定量的に計測す ることを目的とした．具体的には，畑を4つに区切り， 無耕作(裸地)区，サトウキビ春植え栽培(慣行耕起栽培) 区，植生帯を有するサトウキビ春植え栽培区，乙して不 耕起状態でのサトウキビ株出し栽培区の 4 種類の営農形 態で侵食量の同時計測による比較試験を行った. それら の試験結果を用いて，作物の被覆による侵食抑制効果, 不耕起栽培による侵食抑制効果，そして植生帯による流 出土砂の捕捉効果について検討する. 本研究における現 地試験のように，実圃場での同一条件下における複数の 侵食防止対策の同時計測を実施した研究事例は極めて少 ない，また，本研究において定量的に把握した試験結果 は流域一貫土砂管理法の策定のための基礎的資料となる.

\section{2. 試験地の概要および計測方法}

\section{（1）試験地の概要}

試験地は沖縄県石垣市新川におけるサトウキビを栽培 している畑地とした，表層土壌の粒度組成は，国際法に 
よる粒径区分を用いると，粘土 $5 \%$ ，シルト $19 \%$ ，砂 $32 \%$, 礫44\%であった. 図-1に試験地に設置した試験区の概要 を示す. 試験区はSt-1 St-4の4種類あり, St-1を無耕作 (裸地)区，St-2をサトウキビ春植え栽培(慣行耕起栽培)区, St-3を試験区末端に植生帯を有するサトウキビ春植え栽 培区，そしてSt-4を不耕起状態でのサトウキビ株出し栽 培区とした.ここで, St-1の無耕作区は耕起および畧立 てのみを行った状態とした. サトウキビの春植え栽培と は2 3月に苗を植え付け，翌年の1 2月に刈り取る栽培方 法で, 株出し栽培とは刈り取り後の株を用いて生育させ る栽培方法である。 その他のサトウキビの栽培方法とし て，8 9月に苗を植え付け，翌々年の1 2月に刈り取る夏 植え栽培がある．春植えまたは夏植え栽培では1回の栽
培周期の中で数回の耕起を行う。一方, 株出し栽培は苗 の植え付けが省略されるために，1回もしくは2回の慾間 部分のみの耕起を行う．以上の3種類の栽培方法が沖縄 における慣行的な栽培方法である. St-3 の植生帯の植生 には高麗芝を用い，試験区末端より上流に向かい約 $0.6 \mathrm{~m}$ および斜面幅方向全面に植え付けた(図-1参照). $0.6 \mathrm{~m} の$ 植生帯は，沖縄における植生帯対策圃場で一般的に設置 されている長さである. なお， St-2およびSt-3において, 時期によって試験区の位置が変わるのは, 歒立てのため に流路が変更されたためである.

各試験区における営農作業スケジュールを表-1に示寸。 サトウキビの慣行耕起栽培を行っているSt-2およびSt-3 では5回の耕起を行っている. 各試験区の作物および地

\section{St-1:Bare land}

\section{St-2: Sugarcane (annual) \\ St-3: Sugarcane (annual) with grass strip}

\section{St-4: Sugarcane (perennial) by no-tillage farming}

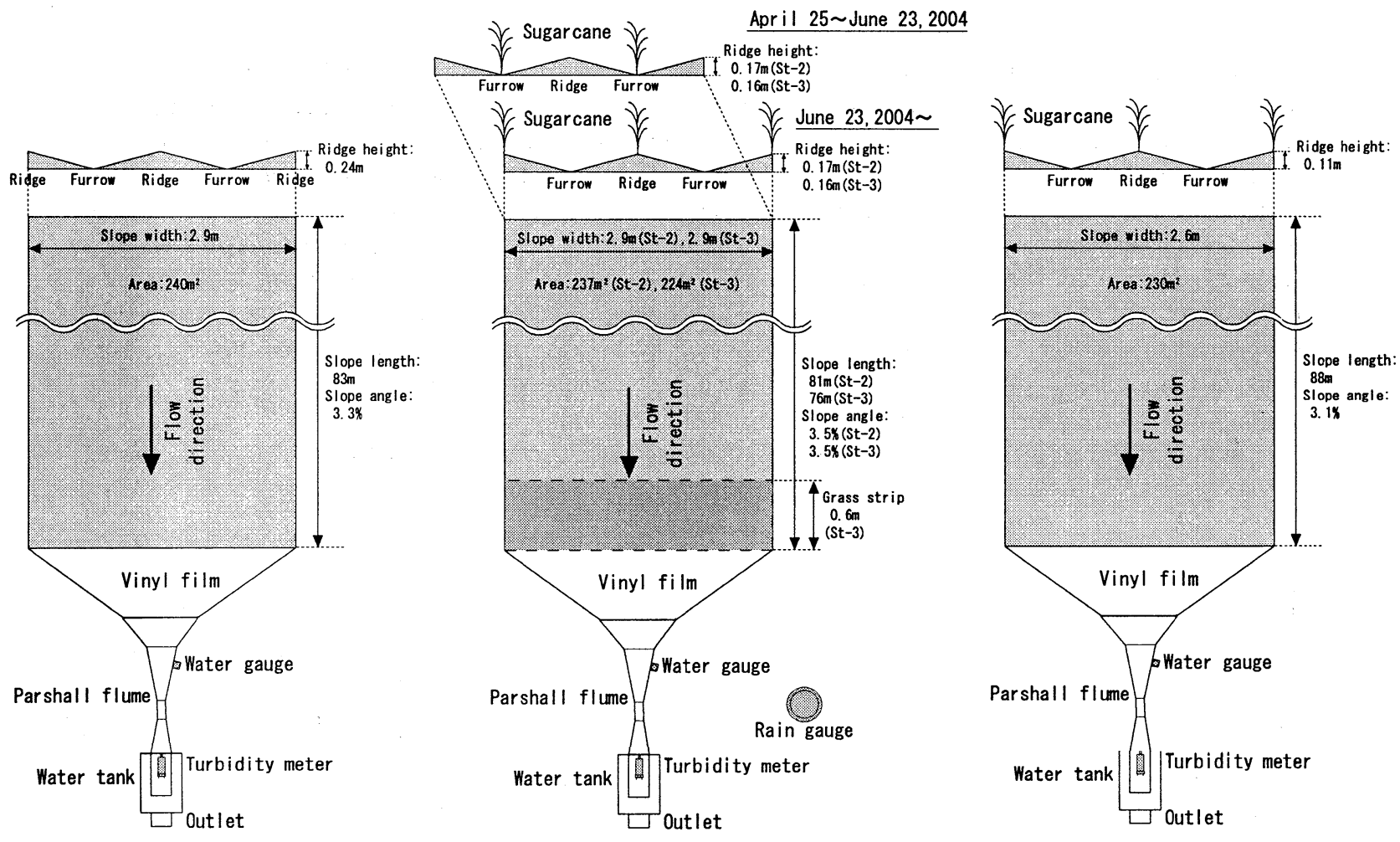

図-1 試験区の概要

表-1＼cjkstart各試験区における営農作業スケジュール

\begin{tabular}{|c|c|c|c|c|c|}
\hline \multicolumn{2}{|c|}{ St-1 } & \multicolumn{2}{|c|}{$\mathrm{St}-2$ and St-3 } & \multicolumn{2}{|c|}{ St-4 } \\
\hline 作業日(年/月/日) & 内容 & 作業日(年/月/日) & 内容 & 作業日(年/月/日) & 内容 \\
\hline $2004 / 4 / 26$ & 耕起 (鋤き起し) & $2003 / 12 / 15$ & 耕起 (鋤き起し) & $2004 / 3 / 10$ & 作物刈り取り \\
\hline $2004 / 5 / 8$ & 耕起 (砕土) & $2004 / 1 / 15$ & 耕起 (鋤き起し) & $2004 / 5 / 31$ & 除草 (薬㶡散布) \\
\hline $2004 / 5 / 8$ & 耕起 (畧立) & $2004 / 2 / 15$ & 耕起 (砕土) & $2004 / 5 / 29$ & 試験開始 \\
\hline $2004 / 5 / 31$ & 試験開始 & $2004 / 2 / 20$ & 苗植え付け & & \\
\hline $2004 / 8 / 8$ & 除草 (薬剤散布) & $2004 / 4 / 25$ & 耕起 (中耕, 畧立) & & \\
\hline $2004 / 8 / 29$ & 除草 (薬剤散布) & $2004 / 6 / 2$ & 試験開始 & & \\
\hline & & $2004 / 6 / 6$ & 植生帯設置 (St-3) & & \\
\hline & & $2004 / 6 / 23$ & 耕起 (培土, 畧立) & & \\
\hline
\end{tabular}


表面の残渣・雑草による被覆率を上空からの画像を用い て算定した．その結果を図-2に示す。測定日は2004年6 月5日，6月24日，9月24日であり，その間は線形で補完 して示した. St-1では7 8月に雑草が繁茂し, 除草剤散 布を行ったので, 地表面の残渣による被覆率が徐々に増 加している. St-2およびSt-3の被覆率の増加は主に作物 の生長によるものである. St-4の被覆率が常時大きいの は，2004年3月の刚り取り直後から生長が始まったこと と地表面の残渣・雑草による被覆が多かったことによる. 2004年6月6日に水準測量を各試験区で行った. 測点は 斜面長方向では約 $10 \mathrm{~m}$ 間隔, 斜面幅方向では畧の山と谷 とした. 本論文ではSt-1の結果のみを図-3に示す. 図よ り雨水は嘼間を流路として流れることがわかる。 なお, 試験期間中においてリルやガリの発生は見られなかった.

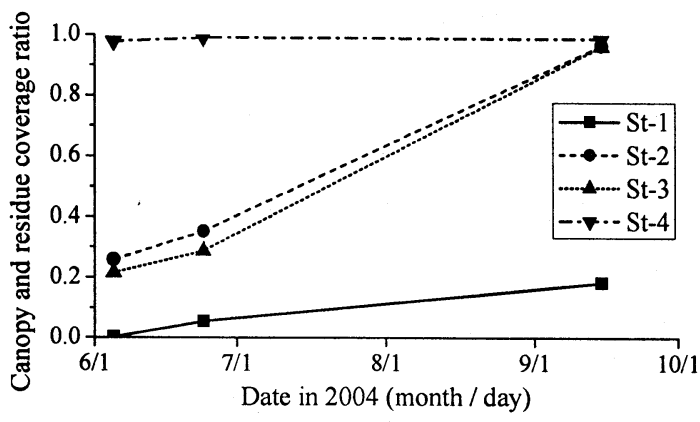

図-2 各試験区における被覆率

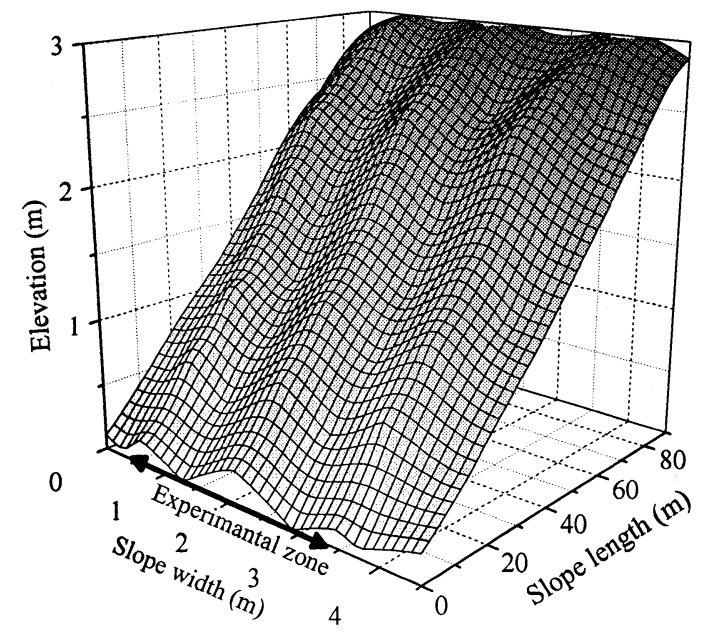

図-3 St-1における地形 (水淮測量の結果)

\section{（2）計測方法}

各試験区における測定項目を表-2に示す. 各測器の設 置場所は図-1に示してある. 流量は検定済みのパーシャ ルフリュームを用いて水位を常時連続計測することに よって換算される. 浮遊土砂濃度は降雨流出時の流水を 採取して吸引濾過法または直接炉乾することによって測 定される. なお, 浮遊土砂を流水中に存在する土粒子 (粒度分布は後述の図-4を参照) と定義する. 取水は手 採水で行われた. 採水時間間隔は流出規模に応じて, 流 量増加時では短く, ピーク後の流量が减少するにつれて
間隔を徐々に長くとった．採水の間の濃度を内挿するた めに濁度計を用いて常時連続計測した. 計測によって得 られた流量と浮遊土砂濃度の積から浮遊士砂流出量が求 められる。なお，畑地から流出したがパーシャルフ リュームまで運搬されず集水部に堆積した土砂は降雨毎 に浚渫し, 乾燥重量を求めた。試験は2004年6月から継 続して行っており，2005年の作物の収穫時期まで行う予 定としている. 本論文では2004年6月から9月の雨天時に おける試験結果について論じる.

表-2 各試験区における測定項目

\begin{tabular}{|c|c|c|}
\hline 項目 & 時間間隔 & 測定機器 \\
\hline 流量 & - & $\begin{array}{l}\text { パーシャルフリューム } \\
\text { (3インチ型,(株)ウイジン) }\end{array}$ \\
\hline 水位 & 1分 & $\begin{array}{l}\text { フロート式水位計 } \\
\text { (UIZ-GY30,(株)ウイジン) }\end{array}$ \\
\hline 濁度 & 2 5分 & $\begin{array}{l}\text { 後方錯乱光式濁度計 } \\
\text { (COMPACT-CLW, (株)アレック電子) }\end{array}$ \\
\hline 採水 & 1 15分* & 手採水 \\
\hline 降水量 & 1分 & $\begin{array}{l}\text { 転倒マス式雨量計 } \\
\text { (MW-010,(株)栄弘精機) }\end{array}$ \\
\hline
\end{tabular}

\section{3. 計測結果}

\section{(1) 流出土砂の粒度分布}

降雨時に採水した流出水に含まれる土砂の粒度分布を レーザー回折式粒度分析計 (SALD-3100, 島津製作所) によって測定した. 本論文ではSt-1における6月8日のイ ベントのピーク部分の粒径加積曲線を図-4に示す. 粒径 は0.1 $\mu \mathrm{m}$ から $100 \mu \mathrm{m}$ の範囲内で存在し, 図に示した以外 の試験区およびイベントの試料もこの範囲内にあった. 図の左上に示した流量と浮遊土砂濃度の経時変化と対応 させて粒度分布の変化を見ると, 流量または濃度の増大 に伴って曲線は右にシフトし, 組成が粗くなる. その後, 流量または濃度の減少に伴って曲線は左へシフトし, 組 成はピーク前の状態へ近づく.

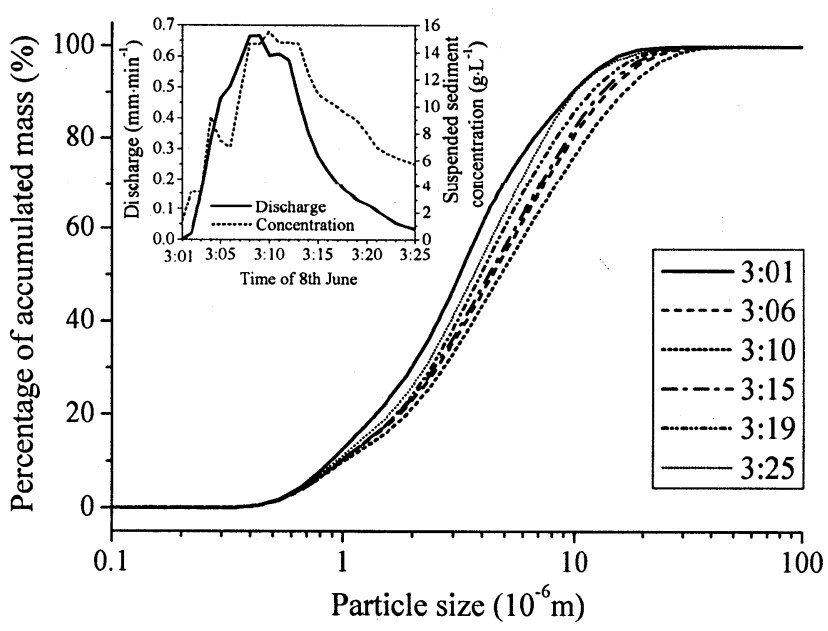

図-4 St-1の流出水に含まれる土砂の粒度分布(2004年6月8日) 
（2）降水量, 流量, 浮遊土砂濃度の経時変化

試験期間中における降水量, 流出高, 浮遊土砂濃度の 経時変化を図-5に示す．図は降雨に伴うイベント部のみ を抜き出して示してある．イベントの区分方法は USLE(Universal Soil Loss Equation)で定義された侵食性の 一連降雨 (降水量が $12.7 \mathrm{~mm}$ 以上または最大 15 分間降水 量が6.4mm以上の降雨で，降雨後の無降雨期間が6時間 以上)に基づいて決定した．それぞれの降雨における確 率降雨年を鈴木・寺川の手法 ${ }^{1)}$ で求めた結果，6月9 10 日が2.6年, その他の降雨は1年以下と算定された.

流量は各試験区の単位面積あたりの流出高として示し た. St-4では他の区画よりピーク時刻が遅く，ピーク後 も緩やかに減少する傾向にあった。これは，作物の雨滴 遮断および樹幹流および地表面の残渣およひ雑草による 流路抵抗の増大が主要因と考えられる. 一方, その他の 試験区では降雨に対する流出の傾向はほぼ同様であった.

浮遊土砂濃度の経時変化は対策区によって明確に異な る結果となった. St-1では多くのピーク部で他の試験区 より著しく大きいピーク濃度が計測された。 これは, 図-2で示したように被覆率が小さいことが主要因と考え られる.8月11 12日は試験区が雑草で覆われたため, 濃 度がSt-2やSt-3より低い結果となった. St-4では, 他の試 験区の值が大きいため，図において判別することが困難 であるが，降雨に伴う濃度の増大が他の試験区と比較し て著しく小さい，特に，試験期間中で最も確率降雨年が
大きかった6月9 10日のイベントの最大濃度は $1.8 \mathrm{~g} \cdot \mathrm{L}^{-1}$ と 非常に低濃度であった. これは, 被覆率が $98 \%$ と非常に 高いことと, 耕起に伴う土壌の靦乱を全く行っていない ことによるものであると考えられる. 筆者らが以前行っ たサトウキビの株出し栽培围場における現地観測 ${ }^{2)}$ では, 被覆率が $90 \%$ 以上の状態では台風に伴う大きな降雨強度 時(最大 1 時間降水量 : $74 \mathrm{~mm}$ )でも $1 \mathrm{~g} \cdot \mathrm{L}^{-1}$ 以下であったこ とからも，侵食は被覆率および耕起履歴に大きく影響さ れることがわかる．St-2およびSt-3における経時変化は ほぼ同様であった，両試験区の被覆率はほぼ同じである ことを考慮すると，St-3における植生帯の流出浮遊土砂 の捕捉効果は小さいことが予想される. また，2004年9 月以降におけるSt-2およびSt-3は, 作物の生長によって 被覆率が1近くまで増大したため, 図では判別すること が困難であるが，St-4と同等の值をとった.

\section{（3）浮遊土砂流出量の経時変化}

計測によって得られた流量と浮遊土砂濃度の積から浮 遊土砂流出量が求められる. 主要な降雨イベントにおけ る浮遊土砂流出量の経時変化を図-6に示寸. なお, 浮遊 土砂流出量の変動が非常に大きく, 線形の軸では表記が 困難であったため, 対数軸を用いた. 全体的な傾向とし て，St-1の值は，ほぼ全ての降雨イベントにおいて最も 大きいことがわかる. 特に6月9日13:40頃のピーク時に おいて約 $52 \mathrm{~g} \cdot \mathrm{min}^{-1} \cdot \mathrm{m}^{-2}$ と試験期間中で最大值を記録した.

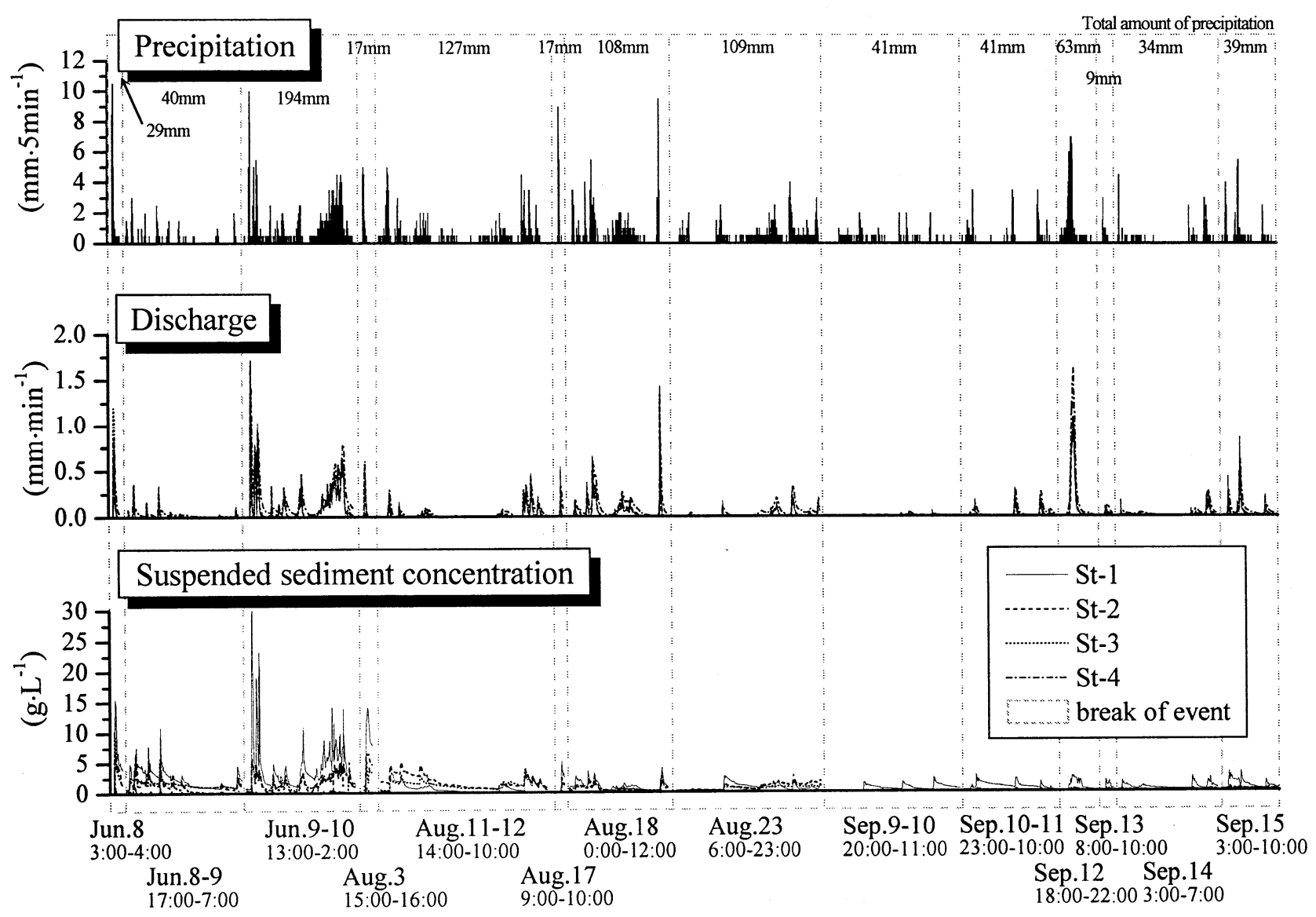

図-5 各試験区における降水量, 流量, 浮遊土砂濃度の経時変化 

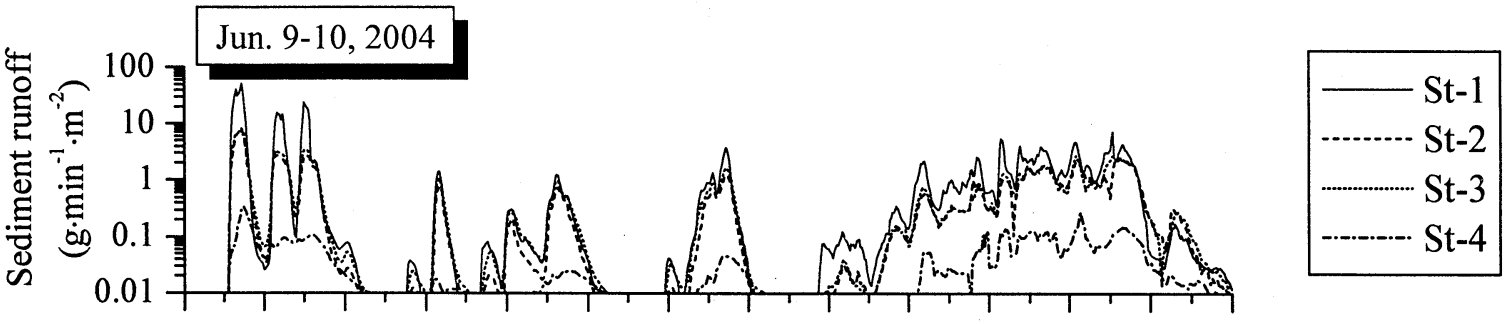

13:00 14:00 15:00 16:00 17:00 18:00 19:00 20:00 21:00 22:00 23:00 0:00 1:00 2:00
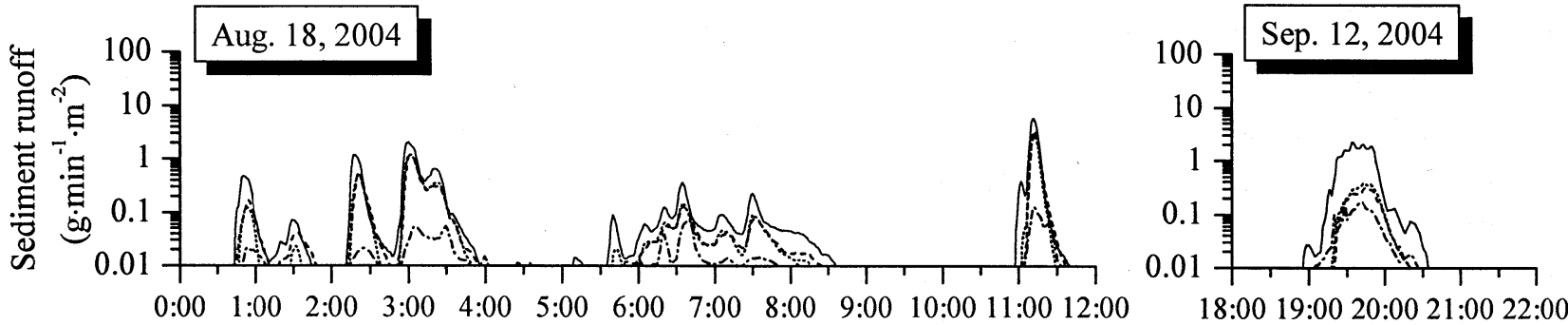

図-6 各試験区における浮遊士砂流出量の経時変化 (上：6月9 10日，左下：8月18日，右下：9月12日)

一方，St-4は全ての降雨に対して，顕著な浮遊土砂流出 が起こっていない，前述の浮遊土砂濃度の経時変化にお ける考察と同様であるが，作物の被覆によって雨滴衝撃 による土粒子の剥離が抑えられ，地表面の被覆によって 流水による土粒子の剥離が抑えられた複合的効果による と考えられる. なお，St-4における試験期間中での浮遊 土砂流出量の最大值は約 $0.5 \mathrm{~g} \cdot \mathrm{min}^{-1} \cdot \mathrm{m}^{-2}$ であり， St-1にお ける最大值の $1 \%$ 以下であった．St-2およびSt-3の経時変 化はほぼ同じであった。

\section{4. 土砂流出抑制対策の検証}

\section{（1）作物の被覆による侵食抑制効果}

サトウキビの慣行耕起栽培方法である春植え栽培の試 験区St-2と無耕作のSt-1を比較することによって，作物 の被覆による侵食抑制効果を検証する，連続計測によっ て得られた浮遊土砂流出量および集水部における堆積土 砂量の和を土砂流出量と定義し，対策区毎および月毎ま たはイベント毎で総計した結果を図-7に示す，合計值で 見るとSt-2はSt-1の41\%であり，削減率は59\%であったこ とがわかる.ここで，St-1またはSt-2の土砂流出量に対 する各試験区における月別の削減率を図-8にまとめた。 白丸印のSt-2の傾向を見ると，生長初期の6月では64\%と なり，8月は比較対象のSt-1で雑草が繁茂し，土砂流出 量が小さかったために削減率が一時低下したが，被覆率 が1近くになる9月では85\%と高い削減率を示した。降雨 イベント毎の削減率は，雑草の影響があった降雨イベン トを除くと39\%(6月8日) 92\%(9月13日)の範囲であった.

以上のように，サトウキビの慣行耕起栽培方法では被 覆率の増大 $(27 \%$ - $97 \%)$ に伴って，士砂流出量を $39 \%$ 92\%の範囲で削減できることが明らかになった. ここで，沖縄県で指針とされている削減率 ${ }^{3)}$ を参照する と，この時期の削減率は50\% 99\%とされており，本研

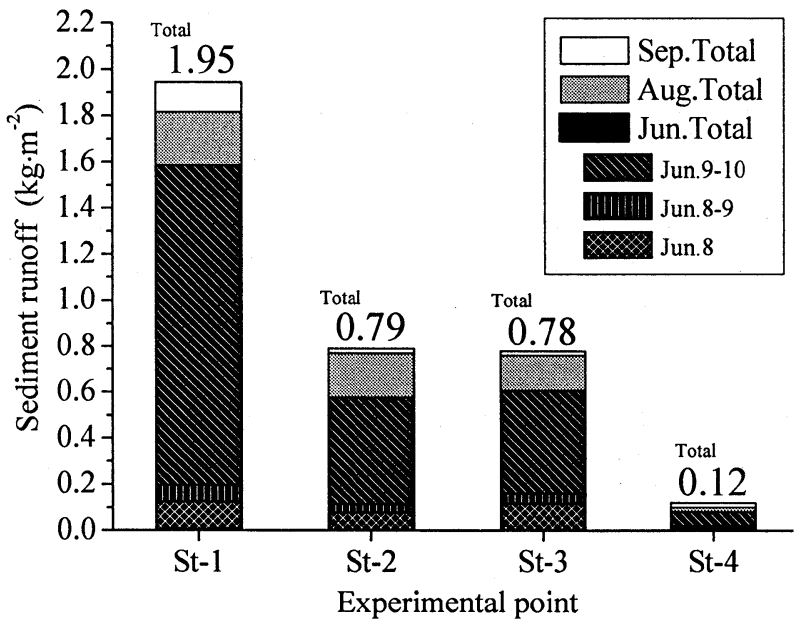

図-7＼cjkstart各試験区における土砂流出量

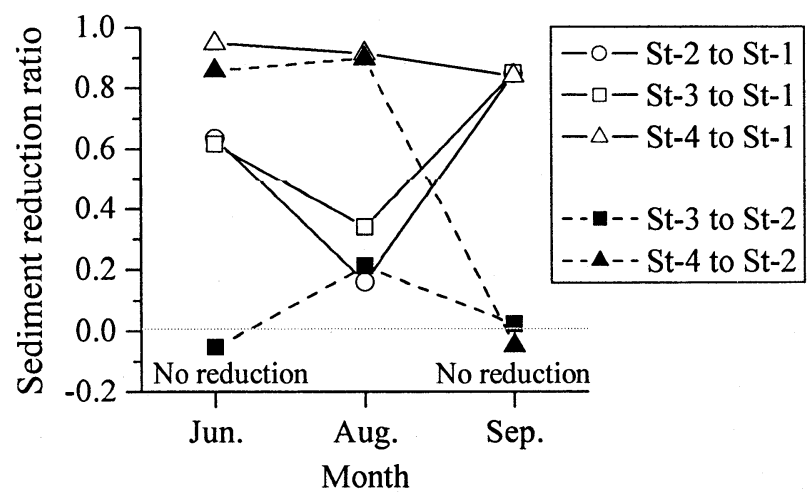

図-8＼cjkstart各試験区における土砂流出量の削減率

究における結果とほぼ同じであつた.

（2）不耕起状態での株出し栽培による侵食抑制効果

St-4の土砂流出量に対する無耕作のSt-1および春植え 栽培のSt-2の土砂流出量を比較することによって，不耕 起状態での株出し栽培による侵食抑制効果を検証する. 
図-7における合計值を見るとSt-4はSt-1 の6\%, St-2の 15\%であり，削減率はそれぞれ $94 \% ， 85 \%$ あった，図一 8における月別の削減率で見ても, St-2の被覆率がSt-4 同程度になる9月の黒三角印を除く全てのイベントにお いて高い削減率であることがわかる。これは，サトウキ ビの株出し栽培は栽培方法上, 新たな苗から生育させる 春植え栽培より生育が早く作物の被覆率が高かったこと， 収穫後, 耕起を行わないことにより土壤の攪乱による侵 食量の増大が無いことや地表面の残渣が多く存在してい たことが侵食抑制に大きく関与したと考えられる.

ここで, 筆者らが沖縄県恩納村の実圃場で行った観測 結果 ${ }^{2)}$ を参照すると, 春植え栽培围場(被覆率34\%) と株 出し栽培戋場(被覆率 $80 \%$ )で同時計測を行った結果, 降 水量 $82 \mathrm{~mm}$ のイベントにおいて土砂流出量はそれぞれ約 $145 \mathrm{~g} \cdot \mathrm{m}^{-2}$, 約 $24 \mathrm{~g} \cdot \mathrm{m}^{-2}$ となり削减率は約 $83 \%$ となった. こ の值は本研究の結果である85\%に近い值である.また, 沖䋥県で指針とされている裸地に対する株出し栽培の削 減率 ${ }^{3)}$ を参照すると，この時期の削減率は90 99\%とさ れており, 本研究における結果はその範囲内にあった.

以上のように, 不耕起状態での株出し栽培は非常に高 い土砂流出抑制効果を有することが明らかになった．し かし, 株出し栽培の収穫量は石垣島で主に行われている 夏植え栽培の収穫量より低いこと, 不耕起栽培は雑草防 除の負担がかかるという営農上の問題点を有する.

\section{（3）植生帯による流出土砂の捕捉効果}

植生帯を有する試験区St-3 と植生帯の無い試験区St-2 の土砂流出量の比較を行い, 植生帯による流出土砂の捕 捉効果を検証する. 図-7の6月8日のイベントにおける土 砂流出量に着目寸ると, St-30土砂流出量が St-2 と比較 して大きい.この降雨イベントは植生帯を設置してから 最初の降雨であったために, 植牛帯部分の土䁃の䚓乱が 影響したと考えられる. よって, 今後, この降雨イベン 卜は考察から除外する. 図-6に示した浮遊土砂流出量の 経時変化を見ると, St-2 と St-3では有意な差は見られな い. 図-7における6月8日のイベントを除いた試験期間全 体の合計值で見ると, $\mathrm{St}-3\left(0.66 \mathrm{~kg} \cdot \mathrm{m}^{-2}\right)$ はSt-2 $\left(0.72 \mathrm{~kg} \cdot \mathrm{m}^{-2}\right)$ の $92 \%$ で, 削減率は $8 \%$ となった。 また, St-2 と St-3の土 砂流出量の差を植生帯の捕捉量と考えると，6月9 10日 のイベントが試験期間における最大值の $3.7 \mathrm{~kg}$ となった. この値は, その時のSt-2における土砂流出量の $109 \mathrm{~kg}$ と 比較すると少ない.

これらの結果から, 実用化されている長さ $0.6 \mathrm{~m} の$ 植生 帯による土砂の捕捉量は, 上流から流出する土砂量に対 して僅かであり, 効果的な削減を行うためには適切でな いことが言える. 十分な量の土砂の捕捉を行うためには, 土砂生産量に見合うだけの植生帯の長さが必要であると 考えられる. 既往の試験結果 ${ }^{4)}$ を参照すると, 沖縄県名 護市における斜面長 $31.5 \mathrm{~m}$, 平均勾配 $2 \%$ の畑地において,

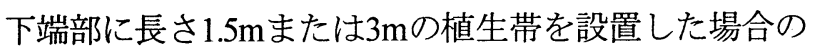

ある一雨(降水量:149mm)に対する土砂流出量の削減率は, それぞれ $51 \%$ \%たは63\%であったと報告されている，な お，土砂の捕捉ではなく，大規模な侵食が起こりやすい 農地と排水路の接合部分の法面保護の目的のために植生 帯を用いることは有効であると考えられる.

\section{5. 結論}

面源からの微細土砂の流出が社会的問題となっている 沖縄において，農地における土砂流出抑制対策に着目し， 実圃場を4つの区画に区切り，それぞれの試験区で各種 対策を施し，同一条件下における土砂流出量の同時計測 を行った. その結果, 以下に示寸知見が得られた.

（1）作物の被覆によって土砂流出は抑制され，被覆率 27\% 97\%のサトウキビの慣行耕起栽培試験区では, 無耕作区に対して39\% 92\%の範囲で土砂流出量を削 減した.

(2) 不耕起状態でのサトウキビの株出し栽培方法は, 地表面における残渣被覆や耕起による土堹挸乱が無 いことなどによって，無耕作状態での土砂流出量の 約 $94 \%$ 削減し，極めて効果的な対策法であった.

(3) 沖縄で実際に設置されている長さ0.6mの植生帯に よる流出土砂の捕捉率は約 $8 \%$ となり, 斜面長約 $80 \mathrm{~m}$ の農地から流出した土砂を有意な削減率で捕捉する ためには十分な長さではない.

本試験は2005年の作物の収穫時期まで行う予定として いる. 今後, これらのデータおよび既往の対策調查事例 を一元的および体系的に整理し, 流域一貫土砂管理法の 策定に向けた最適な対策方法および対策䇢所の合理的判 断手法の開発のための基礎データとする.

謝辞 : 本研究の現地試験にあたり，様々な御支援を頂い た国際農林水産業研究センター沖縄支所の干川明氏およ び試験地の農業者の池原吉克氏に心からお礼を申し上げ ます. なお, この研究は文部科学省科学研究費基盤研究 (A)(2)(課題番号 : 14205070, 研究代表者 : 池田駿介)の 支援によって行われた.

\section{参考文献}

1) 鈴木 俊朗, 寺川陽: アメダスデータを用いた確率降雨量分布の作成, 土木技術資料, Vol. 38, No. 12, pp.20-25, 1996.

2) 大澤 和敏, 酒井一人, 田中 忠次, 吉永 案俊: 降雨每の侵食予測侣 おけるUSLEおよびWEPPの检証，農業土木学会論文集，No.255, pp.43$50,2004$.

3) 比嘉 榮三郎, 大見謝 辰夫, 仲宗根一哉, 満本 裕彰: 沖䋥県にお引 る各種作物の作物俰数, 沖縄県衛生環境研究所報, Vol.31, pp.147-151, 1997.

4) Shiono, T., K. Tamashiro, N. Haraguchi, T. Miyamoto: Use of Vegetation Filter Strips for Reducing Sediment Discharge during a Rainstorm, Participatory Strategy for Soil and Water Conservation, Mihara, M. and Yamaji, E. eds., Institute of Environmental Rehabilitation and Conservation, Japan, pp.55-58, 2004.

（2004.9. 30 受付） 